\title{
Biochar on Soil Fertility and Crop Productivity
}

\author{
Md. Mojammel Haque ${ }^{1}$, Md. Mizanur Rahman ${ }^{1} *$, Md. Monjur Morshed ${ }^{1}$, Md. Shafiqul \\ Islam $^{1}$ and Md. Safiul Islam Afrad ${ }^{2}$ \\ ${ }^{1}$ Department of Soil Science and ${ }^{2}$ Department of Agricultural Extension \& Rural Development, \\ Bangabandhu Sheikh Mujibur Rahman Agricultural University, Gazipur 1706, Bangladesh \\ *Corresponding author and Email: mizan@bsmrau.edu.bd
}

Received: 10 April 2019

Accepted: 09 November 2019

\begin{abstract}
An experiment was conducted at the farmer's field in Shibalaya upazilla of Manikganj district during rabi season of 2017to study the effectiveness of biochar on soil fertility and yields of brinjal and cauliflower. There were five treatments viz. control, recommended inorganic fertilizer (RF), biochar 1 $\mathrm{t} / \mathrm{ha}+\mathrm{RF}$, biochar $3 \mathrm{t} / \mathrm{ha}+\mathrm{RF}$ and biochar $5 \mathrm{t} / \mathrm{ha}+\mathrm{RF}$ laid out in a randomized complete block design with four replications. Data revealed that biochar at the rate of $5 \mathrm{t} / \mathrm{ha}$ along with RF provided maximum yields of brinjal ( $67 \mathrm{t} / \mathrm{ha}$ ) and cauliflower $(42 \mathrm{t} / \mathrm{ha})$. The $\mathrm{pH}$, nutrients and moisture contents of the study soils increased and bulk density decreased with the higher rates of biochar application. Significant changes were observed in the total organic carbon in soils which increased by 25 to $41 \%$ from the initial levels. Recovery, agronomic and physiological efficiencies of N, P, K and S were found the highest with the application of biochar 5 t/ha. In terms of soil fertility and crop productivity application of biochar was found promising and can be recommended as an effective soil management practice.
\end{abstract}

Keywords: Crop productivity, soil fertility, biochar, carbon stock.

\section{Introduction}

Agriculture of Bangladesh faces various challenges of producing crops from its limited land resource to meet up the huge demand for the ever burgeoning population. Climate change, loss of biological diversity, deterioration of land quality, loss of soil fertility, water shortage etc. are the great challenges that make agriculture vulnerable. Moreover, every year cultivated land is reducing due to human settlement, rapid urbanization and industrialization. Therefore, it is necessary to increase crop production through intensification of land with high yielding crop varieties (Rahman and Azam, 2005). Excessive and injudicious use of chemical fertilizers by the farmer threaten soil and human health and degrade agricultural environment and thereby destroy agriculture biodiversity. More than 65\% of the total agricultural land in Bangladesh is suffering from declining soil fertility (FRG, 2012). OM content of soil in Bangladesh is reported to be declining, which is considered to be a very serious problem in agriculture (FRG, 2012). Soil health and its productivity in Bangladesh can't be improved and increased without adopting resource conservation strategies which either maintain or increase OM 
content (Rahman et al., 2016). Soil fertility degradation and available nutrient depletion is common in agroecosystems with environmentally detrimental amounts of modern agricultural practices, which have imbalanced the responsible abiotic and biotic soil fertility factors (Suzuki et al., 2014). Application of OM such as compost, crop residues and animal manure is a traditional practice to reestablish soil nutrient retention capacity (Rahman, 2013). The traditional organic amendments, however, are of short life span in soil and continuous application in bulk quantities diverts its attention of this practice. In this situation biochar appears as a magic solution for increasing $\mathrm{C}$ content, improving soil health and ensuring agricultural sustainability. Biochar is generally produced from the pyrolysis of any kind of waste biomass like rice husk, plant parts, branches, woods, sawdust, bones, sugarcane bi-product, fallen tree leaves, weeds, straw, grasses etc. It is such a product that has various uses in many sectors. But, mainly bicohar is produced as a soil amendment to improve the quality and productivity of soil.

It is a great challenge to keep the agricultural production system sustainable under changing climate. Soils play an essential role in the carbon cycle and account for more than two-thirds of the carbon stocks on terrestrial ecosystems (Lal, 2004). However, soil organic carbon (OC) stocks are fast depleting and thereby lowering the soil fertility. Organic carbon is responsible for soil quality and the formation of aggregates in soils (An et al., 2010). When these are absent the soil clogs up and loses its structure leading to increased erosion and worsening fertility issues. Soil OM is an indicator of its fertility and thereby crop productivity. It is reported that a good and productive soil should contain as a minimum $2.5 \% \mathrm{OM}$, which however, because of conducive climatic condition and rapid microbial decomposition of organic materials in soils of Bangladesh can't be maintained. Most of the soils have less than $1.5 \%$, while some soils even less than 1\% OM (FRG, 2012). To improve the soil physical properties and fertility there is a need to increase the soil OM contents. For this purpose, integrated use of organic and inorganic fertilizer is becoming an emerging trend. As a solution to both the catastrophic state of OC contents in soils and as a climate change mitigation option, the scientific community holds good hopes in biochar (Lehmann, 2007).

Biochar can improve agricultural productivity, particularly in low-fertility and degraded soils where it can be especially useful to the world's poorest farmers; it reduces the losses of nutrients and agricultural chemicals in run-off; it can improve the water-holding capacity of soils; and it is producible from biomass waste (Woolf et al.,2010). The biochar product is believed to be resistant to microbial decomposition (Lim et al., 2016). It has increased crop yield through various mechanisms including stimulation of beneficial soil microbes such as mycorrhizal fungi (Warnock et al., 2007), increase of soil base saturation (Major et al.,2010), increase in water holding capacity (Steiner et al., 2007), and retention of nutrients in the portion of the soil column containing roots, thus improving nutrient use efficiency (Chan et al., 2008; Steiner et al., 2008). It has been shown that biochar substantially improves soil properties and crop yields for acidic and sandy soils (Biederman et al., 2013). Its retention potential also allows for a decrease in fertilizer use (Laird et al., 2010). Biochar will be most promising technology in Bangladesh in response to soil fertility and productivity. Therefore, the present study was designed for assessing the effectiveness of biochar in terms of improving soil health and agricultural sustainability.

\section{Materials and Methods}

\subsection{Experimental site and season}

The experimental site was located at Shibalaya upazilla of Manikgonj which is about $80 \mathrm{~km}$ south-west from Dhaka city. It lies between $23.86^{\circ}$ North latitude and $90^{\circ}$ East longitude with an elevation of $11 \mathrm{~m}$ from sea level, which is under the Young Brahmaputra and Jamuna Floodplain (AEZ 8). The field experiments were 
conducted during rabi season of 2017 using cauliflower (BARI Phulcopy-2) and brinjal (BARI Hybrid Begun-4) as test crops. This area is occupied by permeable silt loam to silty clay loam soils on the ridges and impermeable clays in the basins which are neutral to slightly acidic in reaction. General soil types include predominantly Grey Floodplain soils. Organic matter content is low in ridges and moderate in basins. The climate of the area is tropical monsoon zone. The hot summer, the long rainy season and the pleasant spring cum winter are the main noticeable seasons prevailing in the district. The summer begins at the end of March and is merged with the rainy season that continues up to September. The duration of the winter is recorded from early November to let February.

\subsection{Soil properties of the experimental plots}

Before starting the experiment, soil samples were collected from $0-15 \mathrm{~cm}$ depths of brinjal and cauliflower plots for determining soil moisture, bulk density, organic carbon, soil $\mathrm{pH}$, nitrogen, potassium, phosphorous and sulfur using standard methods (Page et al., 1982). The soil samples were air dried, ground to pass through $2 \mathrm{~mm}$ sieve and used for analysis (Table $1)$.

\subsection{Treatments, experimental design and biochar application}

The field experiments were conducted taking five treatments laid out in a randomized complete block design with four replications. The treatments were control, recommended inorganic fertilizer (RF), biochar $1 \mathrm{t} \mathrm{ha}^{-1}+\mathrm{RF}$, biochar $3 \mathrm{t} \mathrm{ha}^{-1}+\mathrm{RF}$ and biochar $5 \mathrm{tha}^{-1}+\mathrm{RF}$. Biochar was produced in farmer's house while cooking family foods using mahogany wood through 'Akha Chola' provided by Christian Commission for Development of Bangladesh (CCDB). The 'Akha' is a special Chola that makes the fuel wood partially burned and after cooking it is cooled down and grinded to smaller particles for field application. Biochar was analyzed before application to crop field. The moisture content of biochar was $17.3 \%$, and $\mathrm{pH}$ was 7.78 which indicated that biochar was alkaline in nature. Total nitrogen, phosphorus, potassium and carbon contents were $0.89,0.26$, 0.21 and $27 \%$, respectively, with a $\mathrm{C}: \mathrm{N}$ ratio of 30.33. Biochar was applied one week before transplanting of vegetable seedlings to plots.

\subsection{Planting of seedlings, fertilizer and irrigation water application}

Thirty-day old seedlings of cauliflower and thirty five-day old seedlings of brinjal were planted maintaining a spacing of $45 \times 60 \mathrm{~cm}$ and $70 \times 80$ $\mathrm{cm}$, respectively. Soil test based fertilizers were applied. Biochar, potassium from muriate of potash (MoP) and sulphur from gypsum were applied at the time of final land preparation. Phosphorus status of initial soil in crop field was very high and hence $\mathrm{P}$ fertilizer was not applied. The rates of $\mathrm{N}, \mathrm{K}$ and $\mathrm{S}$ for cauliflower were $49.33,42.64$ and $17.75 \mathrm{~kg} / \mathrm{ha}$, respectively, while the rates for brinjal were $71.55,22.0$ and 14.12 $\mathrm{kg} / \mathrm{ha}$, respectively. Nitrogen from urea was applied in three splits. One-third of urea was applied at the time of final land preparation. The remaining two-thirds were top dressed at maximum growth stage and 5-7 days before curd initiation, respectively. In case of brinjal, twothirds were top dressed at maximum growth and flowering stages, respectively. Irrigation water was applied weekly basis. No pesticide was applied as there was no pest infestation during the growing season.

Table 1. Initial soil parameters of brinjal and cauliflower plots

\begin{tabular}{lcccccccc}
\hline Crop fields & $\begin{array}{c}\text { Moisture } \\
(\%)\end{array}$ & $\begin{array}{c}\text { Bulk density } \\
\left(\mathrm{gm} / \mathrm{cm}^{3}\right)\end{array}$ & $\begin{array}{c}\text { Organic } \\
\text { carbon }(\%)\end{array}$ & $\mathrm{pH}$ & $\begin{array}{c}\mathrm{N} \\
(\%)\end{array}$ & $\begin{array}{c}\mathrm{P} \\
(\mathrm{mg} / \mathrm{kg})\end{array}$ & $\begin{array}{c}\mathrm{K} \\
(\mathrm{meq} / 100 \mathrm{~g})\end{array}$ & $\begin{array}{c}\mathrm{S} \\
(\mathrm{mg} / \mathrm{kg})\end{array}$ \\
\hline Cauliflower & 11 & 1.34 & 0.67 & 6.38 & 0.25 & 47.29 & 0.26 & 10.99 \\
Brinjal & 13 & 1.41 & 1.1 & 6.30 & 0.20 & 43.50 & 0.29 & 6.30 \\
\hline
\end{tabular}




\subsection{Carbon stock}

Carbon stock estimated using equation as follows:

$\mathrm{C}$ stock $(\mathrm{t} / \mathrm{ha})=$ Conc. of soil $\mathrm{C}(\%) \mathrm{x}$ soil bulk density (g/c.c.) x soil depth $(\mathrm{cm})$

\subsection{Crop harvesting and collection of plant and soil samples for analysis}

Cauliflower curds and brinjal fruits were collected 5 times and total fresh weights were recorded as $\mathrm{kg} / \mathrm{plot}$ which was then extrapolated to t/ha. Plant samples from each plot were collected after maturing the curd and the fruit of brinjal. Samples were washed with tap water followed by distilled water to remove soil particles. Then the samples were weighed, chopped and dried in room temperature before oven drying at $70^{\circ} \mathrm{C}$ for 72 hours. After drying the samples were weighed for dry matter content. Samples were placed in coin envelopes and dried again before chemical analysis. Post-harvest soil samples (core and composite) were collected from each plots of both cauliflower and brinjal considering a depth of $0-15 \mathrm{~cm}$. The soil samples were air-dried, ground and sieved through a 10 mesh sieve. This air-dried ground samples were stored in the clean plastic bag for subsequent physical and chemical analyses.

\section{Results and Discussion}

\subsection{Biochar on yield and yield contributing parameters of cauliflower and brinjal}

The yields of cauliflower and brinjal were significantly $(\mathrm{p}<0.0005)$ affected by different rates of biochar (Table 2). The restricted growth of cauliflower and brinjal plants were found in the control and fertilizer treated plots where no biochar was applied. Conversely, robust growth of cauliflower and brinjal plants were observed when biochar was applied along with recommended fertilizer (RF). The highest fresh yield of cauliflower $44 \mathrm{t} / \mathrm{ha}$ was noted in $5 \mathrm{t} / \mathrm{ha}$ biochar treatment followed by 36.75 t/ha and $34.63 \mathrm{t} / \mathrm{ha}$ in $3 \mathrm{t} / \mathrm{ha}$ and $1 \mathrm{t} / \mathrm{ha}$ biochar treatments, respectively. Similar findings were also observed in case of brinjal where the highest fresh yield of $66 \mathrm{t} / \mathrm{ha}$ was recorded in $5 \mathrm{t} / \mathrm{ha}$ biochar treatment followed by $57.5 \mathrm{t} / \mathrm{ha}$ and $40.5 \mathrm{t} / \mathrm{ha}$ in $3 \mathrm{t} / \mathrm{ha}$ and $1 \mathrm{t} / \mathrm{ha}$ biochar treatments, respectively. The positive effects of biochar on plant growth and biomass yield have been reported by a number of researchers (Uzoma et al., 2011; Kimetu et al., 2008; Lehmann et al., 2003). Biochar brings multiple benefits in managing soil health and crop production. Biochar improves soil physical properties that helps conserve soil nutrients and supplies upon crop requirements.

\subsection{Effect of biochar on nutrient concentration in plant and uptake by plant}

The concentrations of most of the nutrients in the curd of cauliflower and brinjal plants were affected by biochar application. There were clear differences in concentrations of different elements for different biochar doses which are presented in Table 3 . The highest concentration was observed in the highest biochar treatment for $\mathrm{N}, \mathrm{P}, \mathrm{K}$ and $\mathrm{S}$ in both the crops.

Table 2. Effect of different treatments on fresh yield and dry matter yield of cauliflower

\begin{tabular}{lcccc}
\hline \multirow{2}{*}{ Treatments } & \multicolumn{2}{c}{ Cauliflower } & \multicolumn{2}{c}{ Brinjal } \\
\cline { 2 - 5 } & $\begin{array}{c}\text { Fresh yield } \\
(\mathrm{t} / \mathrm{ha})\end{array}$ & $\begin{array}{c}\text { Dry matter } \\
\text { yield (t/ha) }\end{array}$ & $\begin{array}{c}\text { Fresh yield } \\
(\mathrm{t} / \mathrm{ha})\end{array}$ & $\begin{array}{c}\text { Dry matter } \\
\text { yield (t/ha) }\end{array}$ \\
\hline Control Plot & $15.25 \mathrm{~d}$ & $1.31 \mathrm{c}$ & $13.25 \mathrm{e}$ & $0.93 \mathrm{e}$ \\
Recommended fertilizer (RF) & $29.50 \mathrm{c}$ & $2.24 \mathrm{~b}$ & $25.5 \mathrm{~d}$ & $1.56 \mathrm{~d}$ \\
$1 \mathrm{t} / \mathrm{ha}$ Biochar + RF & $34.63 \mathrm{~b}$ & $2.80 \mathrm{~b}$ & $40.5 \mathrm{c}$ & $2.84 \mathrm{c}$ \\
$3 \mathrm{t} /$ ha Biochar + RF & $36.75 \mathrm{~b}$ & $2.57 \mathrm{~b}$ & $57.5 \mathrm{~b}$ & $4.51 \mathrm{~b}$ \\
$5 \mathrm{t} / \mathrm{ha}$ Biochar + RF & $44.00 \mathrm{a}$ & $3.73 \mathrm{a}$ & $66 \mathrm{a}$ & $5.66 \mathrm{a}$ \\
\hline $\mathrm{CV}(\%)$ & 4.31 & 15.21 & 8.60 & 8.74 \\
$\mathrm{SE}( \pm)$ & 0.98 & 0.27 & 2.47 & 0.19 \\
\hline
\end{tabular}


Table 3. Effect of different treatments on nutrient content in cauliflower and Brinjal

\begin{tabular}{lcccccccc}
\hline Treatments & \multicolumn{7}{c}{ Concentrations of different nutrients (\%) } \\
\cline { 2 - 9 } & \multicolumn{7}{c}{ Cauliflower } & \multicolumn{5}{c}{ Brinjal } \\
\cline { 2 - 9 } & $\mathrm{N}$ & $\mathrm{P}$ & $\mathrm{K}$ & $\mathrm{S}$ & $\mathrm{N}$ & $\mathrm{P}$ & $\mathrm{K}$ & $\mathrm{S}$ \\
\hline Control Plot & $0.94 \mathrm{~d}$ & $0.15 \mathrm{~d}$ & $1.47 \mathrm{~d}$ & $0.16 \mathrm{~d}$ & $0.72 \mathrm{c}$ & $0.32 \mathrm{c}$ & $0.15 \mathrm{~d}$ & $0.2 \mathrm{c}$ \\
Recommended & $1.19 \mathrm{c}$ & $0.20 \mathrm{c}$ & $1.62 \mathrm{c}$ & $0.22 \mathrm{c}$ & $1.05 \mathrm{~b}$ & $0.34 \mathrm{bc}$ & $0.27 \mathrm{c}$ & $0.24 \mathrm{c}$ \\
fertilizer (RF) & & & & & & & & \\
$1 \mathrm{t} /$ ha Biochar + RF & $1.80 \mathrm{~b}$ & $0.18 \mathrm{c}$ & $1.74 \mathrm{~b}$ & $0.28 \mathrm{~b}$ & $1.15 \mathrm{~b}$ & $0.36 \mathrm{abc}$ & $0.31 \mathrm{c}$ & $0.25 \mathrm{c}$ \\
$3 \mathrm{t} / \mathrm{ha}$ Biochar + RF & $1.79 \mathrm{~b}$ & $0.27 \mathrm{~b}$ & $1.79 \mathrm{~b}$ & $0.30 \mathrm{ab}$ & $1.40 \mathrm{a}$ & $0.40 \mathrm{ab}$ & $0.46 \mathrm{~b}$ & $0.31 \mathrm{~b}$ \\
$5 \mathrm{t} / \mathrm{ha}$ Biochar + RF & $1.91 \mathrm{a}$ & $0.31 \mathrm{a}$ & $1.87 \mathrm{a}$ & $0.32 \mathrm{a}$ & $1.50 \mathrm{a}$ & $0.41 \mathrm{a}$ & $0.63 \mathrm{a}$ & $0.38 \mathrm{a}$ \\
\hline $\mathrm{CV} \%$ & 2.46 & 7.68 & 2.99 & 7.16 & 12.15 & 13.26 & 13.60 & 12.35 \\
$\mathrm{SE}( \pm)$ & 0.03 & 0.01 & 0.04 & 0.01 & 0.09 & 0.03 & 0.03 & 0.02 \\
\hline
\end{tabular}

The increment rates of $\mathrm{N}, \mathrm{P}, \mathrm{K}$ and $\mathrm{S}$ in cauliflower were found $60,55,15$, and $45 \%$, respectively in biochar 5 t/ha plus RF treatment compared to the RF alone treatment, while in case of brinjal nutrient increment rates were 43, 21, 133 and 58\%, respectively. The concentrations of different elements in the control treatment were generally lower, and the control treatment had the lowest concentrations for $\mathrm{N}, \mathrm{P}, \mathrm{K}$ and $\mathrm{S}$. This result is expected, because the available concentrations of most of the nutrients in soil were highest in the highest biochar dose. Similar trend was reported by Angst and Sohi (2013) and Yao et al. (2013) where they stated that biochar adsorbs $\mathrm{N}$ and $\mathrm{P}$ more efficiently and makes available over a period of time for plant uptake which stimulates the plant growth.

Table 4 indicates that nutrient uptake among the treatments were significantly varied. Nitrogen, phosphorous, potassium and sulfur uptake were significantly influenced by biochar application. The $\mathrm{N}$ uptake of curd varied between 12.34 to $71.13 \mathrm{~kg} / \mathrm{ha}$. The highest $\mathrm{N}$ uptake of curd $(71.13$ $\mathrm{kg} / \mathrm{ha}$ ) was recorded in the treatment of $5 \mathrm{t} / \mathrm{ha}$ biochar + RF and the lowest of $12.34 \mathrm{~kg} / \mathrm{ha}$ was recorded in absolute control plot. In case of brinjal, $\mathrm{N}$ uptake varied between 6.71 to 85 $\mathrm{kg} / \mathrm{ha}$. The highest $\mathrm{N}$ uptake of brinjal $(85 \mathrm{~kg} / \mathrm{ha})$ was recorded in the treatment of $5 \mathrm{t} / \mathrm{ha}$ biochar + $\mathrm{RF}$ and the lowest of $6.71 \mathrm{~kg} / \mathrm{ha}$ was recorded in absolute control plot.
The $\mathrm{P}$ uptake of curd varied between 1.97 to $11.32 \mathrm{~kg} / \mathrm{ha}$, while the highest $(11.32 \mathrm{~kg} / \mathrm{ha})$ was recorded in the treatment of $5 \mathrm{t} / \mathrm{ha}$ biochar $+\mathrm{RF}$ and the lowest of $1.97 \mathrm{~kg} / \mathrm{ha}$ was recorded in absolute control plot. In case of brinjal, $\mathrm{P}$ uptake varied between 2.96 to $23.01 \mathrm{~kg} / \mathrm{ha}$ where the highest $\mathrm{P}$ uptake of brinjal $(23.01 \mathrm{~kg} / \mathrm{ha})$ was recorded in the treatment of $5 \mathrm{t} / \mathrm{ha}$ biochar $+\mathrm{RF}$ and the lowest uptake of $2.96 \mathrm{~kg} / \mathrm{ha}$ was recorded in absolute control plot.

The K uptake of curd varied between 19.27 to $69.84 \mathrm{~kg} / \mathrm{ha}$ where the highest $\mathrm{K}$ uptake of curd $(69.84 \mathrm{~kg} / \mathrm{ha})$ was recorded in the treatment of 5 $\mathrm{t} /$ ha biochar $+\mathrm{RF}$ and the lowest $\mathrm{K}$ uptake of $19.27 \mathrm{~kg} / \mathrm{ha}$ was recorded in absolute control plot. In case of brinjal, $\mathrm{K}$ uptake varied between 1.32 to $35.82 \mathrm{~kg} / \mathrm{ha}$, while the highest uptake $(35.82 \mathrm{~kg} / \mathrm{ha})$ was recorded in the treatment of 5 $\mathrm{t} /$ ha biochar $+\mathrm{RF}$ and the lowest uptake of 1.32 $\mathrm{kg} / \mathrm{ha}$ was recorded in absolute control plot.

The S uptake of curd varied between 2.07 to $11.51 \mathrm{~kg} / \mathrm{ha}$ at harvest stage. The highest $\mathrm{S}$ uptake of curd $(11.51 \mathrm{~kg} / \mathrm{ha})$ was recorded in the treatment of $5 \mathrm{t} / \mathrm{ha}$ biochar $+\mathrm{RF}$ and the lowest of $2.07 \mathrm{~kg} / \mathrm{ha}$ was recorded in absolute control plot (Table 4.9). In case of brinjal, the $S$ uptake of curd varied between 1.91 to $21.3 \mathrm{~kg} / \mathrm{ha}$. The highest $\mathrm{S}$ uptake of curd $(21.3 \mathrm{~kg} / \mathrm{ha})$ was recorded in the treatment of $5 \mathrm{t} / \mathrm{ha}$ biochar $+\mathrm{RF}$ and the lowest $\mathrm{N}$ uptake of $1.91 \mathrm{~kg} / \mathrm{ha}$ was recorded in absolute control plot. 
Table 4. Effect of different treatments on total uptake of nutrients in cauliflower and brinjal

\begin{tabular}{|c|c|c|c|c|c|c|c|c|}
\hline \multirow{3}{*}{ Treatments } & \multicolumn{8}{|c|}{ Uptake of different nutrients $(\mathrm{kg} / \mathrm{ha})$} \\
\hline & \multicolumn{4}{|c|}{ Cauliflower } & \multicolumn{4}{|c|}{ Brinjal } \\
\hline & $\mathrm{N}$ & $\mathrm{P}$ & $\mathrm{K}$ & $\mathrm{S}$ & $\mathrm{N}$ & $\mathrm{P}$ & $\mathrm{K}$ & $\mathrm{S}$ \\
\hline Control Plot & $12.34 \mathrm{~d}$ & $1.97 \mathrm{~d}$ & $19.27 \mathrm{~d}$ & $2.07 \mathrm{~d}$ & $6.71 \mathrm{~d}$ & $2.96 \mathrm{~d}$ & $1.32 \mathrm{~d}$ & $1.91 \mathrm{e}$ \\
\hline $\begin{array}{l}\text { Recommended } \\
\text { fertilizer (RF) }\end{array}$ & $26.51 \mathrm{c}$ & $4.44 \mathrm{c}$ & $36.15 \mathrm{c}$ & $4.80 \mathrm{c}$ & $16.1 \mathrm{~d}$ & $5.62 \mathrm{~d}$ & $4.14 \mathrm{~d}$ & $3.77 \mathrm{~d}$ \\
\hline 1 t/ha Biochar + RF & $50.45 \mathrm{~b}$ & $5.17 \mathrm{bc}$ & $48.79 \mathrm{~b}$ & $7.77 \mathrm{~b}$ & $33.06 \mathrm{c}$ & $9.47 \mathrm{c}$ & $8.78 \mathrm{c}$ & $6.95 \mathrm{c}$ \\
\hline 3 t/ha Biochar + RF & $45.79 \mathrm{~b}$ & $6.73 \mathrm{~b}$ & $45.82 \mathrm{bc}$ & $7.66 \mathrm{~b}$ & $62.94 \mathrm{~b}$ & $18.44 b$ & $20.38 \mathrm{~b}$ & $14.04 \mathrm{~d}$ \\
\hline 5 t/ha Biochar + RF & $71.13 \mathrm{a}$ & $11.32 \mathrm{a}$ & $69.84 \mathrm{a}$ & $11.51 \mathrm{a}$ & $85 \mathrm{a}$ & $23.01 \mathrm{a}$ & $35.82 \mathrm{a}$ & $21.3 \mathrm{a}$ \\
\hline $\mathrm{CV} \%$ & 17.88 & 19.43 & 16.96 & 17.00 & 15.10 & 17.30 & 15.01 & 11.68 \\
\hline $\operatorname{SE}( \pm)$ & 5.21 & 0.81 & 5.27 & 0.81 & 4.35 & 1.46 & 1.50 & 0.79 \\
\hline
\end{tabular}

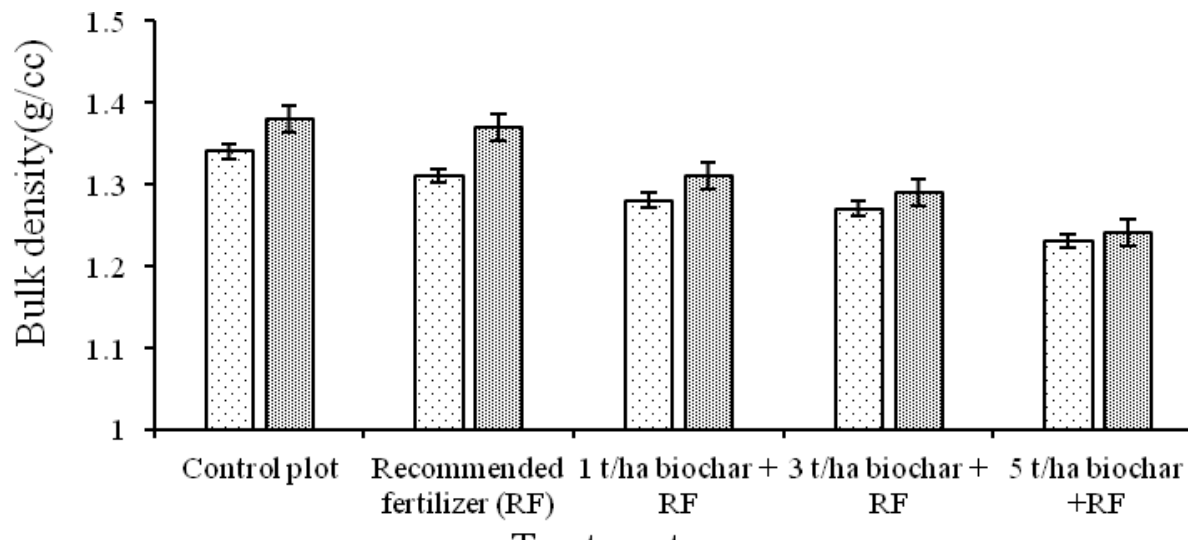

Treatments

\section{$\square$ Cauliflower Brinjal}

Figure 1. Effect of different rates of biochar on soil bulk density

\subsection{Effect of biochar on physical properties of soil}

The changes of soil bulk densities were found significant $(\mathrm{p}<0.05)$ among the different rates of biochar application. The lowest soil bulk density was obtained from 5 t/ha biochar application, and it was significantly lower $(\mathrm{p}<0.05)$ than that of 1 and 3 t/ha biochar treatments in both the crops. The lowest (1.23) and highest (1.34) soil bulk densities were recorded from $5 \mathrm{t} / \mathrm{ha}$ biochar $+\mathrm{RF}$ and without biochar applied soil in cauliflower fields, respectively. Similar findings were recorded in case of brinjal as well, i.e. the lowest (1.24) and highest (1.38) soil bulk density were recorded from 5 t/ha biochar $+\mathrm{RF}$ and without biochar applied soil, respectively. Biochar can increase the total porosity of soil and a decrease in bulk density with increasing biochar addition. Bulk density of soil might decrease through addition of biochar, especially at high application rates, due to its relatively lower bulk density compared to mineral particles (Lehmann et al., 2011).

Moisture contents in soil as affected by different rates of biochar application are depicted in the Fig. 2. It was found that the soils that received higher amount of biochar retained more moisture and the difference was statistically significant among the treatments. The highest $(16.75 \%)$ and 
lowest $(11.5 \%)$ soil moisture were recorded from $5 \mathrm{t} /$ ha biochar + RF and without biochar applied soil in cauliflower fields, respectively. Treatments performed similarly in case of brinjal as well where the highest $(20.25 \%)$ and the lowest $(13.75 \%)$ soil moisture were recorded from $5 \mathrm{t} /$ ha biochar $+\mathrm{RF}$ and without biochar applied fields, respectively.

\subsection{Effects of biochar on organic carbon and carbon stock in soils}

The effect of biochar application on soil organic matter was highly significant. The highest soil organic carbon was obtained from $5 \mathrm{t} / \mathrm{ha}$ biochar $+\mathrm{RF}$ application in both the cases which was significantly higher $(\mathrm{p}<0.05)$ than that of other treatments, while the lowest carbon was attributed in the control treatment where no biochar was added (Table 5). Significantly highest amounts of organic carbon in soils were $0.89 \%$ and $1.29 \%$ found in cauliflower and brinjal fields, respectively, while the lowest carbon contents $0.61 \%$ and $0.96 \%$ were found in the control treatments under cauliflower and brinjal fields, respectively. As carbon concentrations were found higher with higher doses of biochar application, accordingly carbon stocks were also found higher in higher rates of biochar treatments. The maximum stocks of carbon were attributed $15.74 \mathrm{t} / \mathrm{ha}$ and $23.95 \mathrm{t} / \mathrm{ha}$ in cauliflower and brinjal fields when biochar was applied at the rate of $5 \mathrm{t} / \mathrm{ha}$. Biochar is a pyrolized organic product which is more stable in soils and microbial decomposition is very slow.

Therefore, biochar application contributed to higher carbon percentage and carbon stock in soils. There are extensive literature reviews about the use of biochar to mitigate climate change by increasing carbon storage in soils (Lehmann et al., 2011). The positive effects of biochar application to increase carbon contents and carbon stock and to improve soil biophysico-chemical properties were reported by many researchers (Yamato et al., 2006; Major et al., 2010).

\subsection{Effect of biochar on chemical properties of soil}

The effect of biochar application on soil $\mathrm{pH}$ was found significant among the treatments in both the cauliflower and brinjal plots but it was increased with higher rates of biochar application. Therefore, higher the dose of application of biochar, greater was the increment in soil $\mathrm{pH}$ (Table 6). The application of different doses of biochar increased the soil $\mathrm{pH}$ gradually. The highest soil $\mathrm{pH}$ was observed in the soil treated with 5 t/ha biochar + Recommended fertilizer (RF) which were 6.81 and 6.59, while the lowest was recorded from the control plot which were 6.40 and 6.27 in cauliflower and brinjal fields, respectively. This shows that biochar application has great influence on change in $\mathrm{pH}$ of the soil.

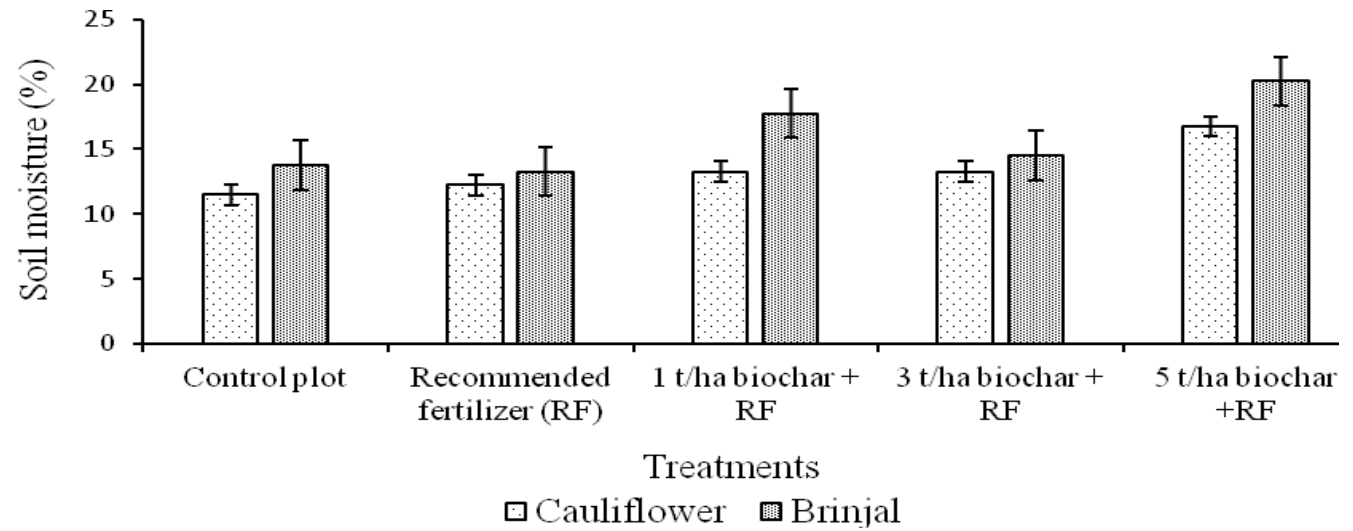

Figure 2. Effect of different rates of biochar on soil moisture 
Table 5. Effect of different treatments on organic carbon and carbon stock in soils under cauliflower and brinjal fields

\begin{tabular}{lcccc}
\hline Treatments & \multicolumn{2}{c}{ Cauliflower } & \multicolumn{2}{c}{ Brinjal } \\
\cline { 2 - 5 } & $\begin{array}{c}\text { Organic carbon } \\
(\%)\end{array}$ & C stock (t/ha) & $\begin{array}{c}\text { Organic carbon } \\
(\%)\end{array}$ & $\begin{array}{c}\text { C stock } \\
(\mathrm{t} / \mathrm{ha})\end{array}$ \\
\hline Control Plot & $0.61 \mathrm{~d}$ & $12.16 \mathrm{c}$ & $0.96 \mathrm{c}$ & $19.87 \mathrm{~b}$ \\
Recommended fertilizer & $0.68 \mathrm{~cd}$ & $13.27 \mathrm{bc}$ & $1.11 \mathrm{~b}$ & $22.77 \mathrm{a}$ \\
$(\mathrm{RF})$ & & & & \\
1 t/ha Biochar + RF & $0.74 \mathrm{bc}$ & $14.24 \mathrm{ab}$ & $1.16 \mathrm{~b}$ & $22.85 \mathrm{a}$ \\
$3 \mathrm{t} / \mathrm{ha}$ Biochar + RF & $0.82 \mathrm{ab}$ & $15.64 \mathrm{a}$ & $1.15 \mathrm{~b}$ & $22.18 \mathrm{a}$ \\
$5 \mathrm{t} / \mathrm{ha}$ Biochar + RF & $0.86 \mathrm{a}$ & $15.74 \mathrm{a}$ & $1.29 \mathrm{a}$ & $23.95 \mathrm{a}$ \\
\hline $\mathrm{CV} \%$ & 8.61 & 8.37 & 6.38 & 6.51 \\
$\mathrm{SE}( \pm)$ & 0.05 & 0.84 & 0.05 & 1.03 \\
\hline
\end{tabular}

Table 6. Effect of different treatments on chemical properties of soil

\begin{tabular}{|c|c|c|c|c|c|c|c|c|c|c|}
\hline \multirow[t]{2}{*}{ Treatments } & \multicolumn{5}{|c|}{ Cauliflower } & \multicolumn{5}{|c|}{ Brinjal } \\
\hline & $\mathrm{pH}$ & $\begin{array}{l}\mathrm{N} \\
(\%)\end{array}$ & $\begin{array}{c}\mathrm{P} \\
(\mathrm{ppm})\end{array}$ & $\begin{array}{c}\mathrm{K} \\
\text { (meq/ } \\
100 \mathrm{~g}) \\
\end{array}$ & $\begin{array}{c}\mathrm{S} \\
(\mathrm{ppm})\end{array}$ & $\mathrm{pH}$ & $\begin{array}{l}\mathrm{N} \\
(\%)\end{array}$ & $\begin{array}{c}\mathrm{P} \\
(\mathrm{ppm})\end{array}$ & $\begin{array}{c}\mathrm{K} \\
\text { (meq/ } \\
100 \mathrm{~g})\end{array}$ & $\begin{array}{c}\mathrm{S} \\
(\mathrm{ppm})\end{array}$ \\
\hline Control Plot & $6.40 \mathrm{c}$ & $0.16 \mathrm{c}$ & $48.37 \mathrm{bc}$ & $0.27 b$ & $3.31 b$ & $6.27 \mathrm{~d}$ & $0.13 \mathrm{~d}$ & $46.05 \mathrm{~d}$ & $0.32 \mathrm{c}$ & $3.8 \mathrm{c}$ \\
\hline $\begin{array}{l}\text { Recommended } \\
\text { fertilizer (RF) }\end{array}$ & $6.51 \mathrm{c}$ & $0.20 \mathrm{c}$ & $56.88 \mathrm{ab}$ & $0.30 \mathrm{ab}$ & $4.00 \mathrm{~b}$ & $6.34 c$ & $0.22 \mathrm{c}$ & $56.65 \mathrm{bc}$ & $0.32 b c$ & $4.93 b c$ \\
\hline $\begin{array}{l}1 \mathrm{t} / \mathrm{ha} \text { Biochar } \\
+\mathrm{RF}\end{array}$ & $6.74 \mathrm{ab}$ & $0.22 b c$ & 44.11c & $0.34 \mathrm{a}$ & $2.45 b$ & $6.39 b c$ & $0.26 b c$ & $49.83 \mathrm{~cd}$ & $0.36 b c$ & $5.83 b$ \\
\hline $\begin{array}{l}3 \mathrm{t} / \mathrm{ha} \text { Biochar } \\
+\mathrm{RF}\end{array}$ & $6.64 b$ & $0.32 \mathrm{~b}$ & $67.30 \mathrm{a}$ & $0.31 \mathrm{ab}$ & $3.78 b$ & $6.40 \mathrm{~b}$ & $0.30 \mathrm{~b}$ & 61.66ab & $0.38 b$ & $6.08 \mathrm{~b}$ \\
\hline $\begin{array}{l}5 \mathrm{t} / \mathrm{ha} \text { Biochar } \\
+\mathrm{RF} \\
\end{array}$ & $6.81 \mathrm{a}$ & $0.37 \mathrm{a}$ & $56.84 \mathrm{ab}$ & $0.32 \mathrm{ab}$ & $7.38 \mathrm{a}$ & $6.59 \mathrm{a}$ & $0.41 \mathrm{a}$ & $68.05 \mathrm{a}$ & $0.47 \mathrm{a}$ & $9.5 \mathrm{a}$ \\
\hline$\overline{\mathrm{CV} \%}$ & 1.14 & 24.67 & 13.28 & 13.82 & 51.77 & 0.6 & 13.11 & 11.76 & 9.76 & 18.19 \\
\hline $\mathrm{SE}( \pm)$ & 0.05 & 0.04 & 5.14 & 0.03 & 1.5 & 0.03 & 0.02 & 4.7 & 0.03 & 0.8 \\
\hline
\end{tabular}

Biochar has liming ability due to its intrinsically high $\mathrm{pH}$ and concentration of basic cations retained from the initial feedstock, including $\mathrm{Ca}$, $\mathrm{Mg}$, and $\mathrm{K}$ (Beesley et al.,2011; Laird et al.,2010; Lehmann et al., 2011). There are a number of studies which showed that soil $\mathrm{pH}$ increased due to biochar amendments especially in acidic soil (Yuan and Xu, 2011; Yamato et al., 2006; Major et al., 2010). The increased in soil $\mathrm{pH}$ attributed from the integration of highly alkaline nature of biochars, high base cation concentration which in turn released protons into the soil solution and the acidity reduced through proton consumption reaction and higher availability of $\mathrm{CaCO}_{3}$.

The total nitrogen content of the initial soil was $0.25 \%$ but after addition of biochar, the total nitrogen increased in case of cauliflower plot. In the $5 \mathrm{t} /$ ha biochar $+\mathrm{RF}$ treatment contained the highest total nitrogen which was $0.37 \%$, while in the control treatment was $0.16 \%$ (Table 6). In the treatment 1 and 3 t/ha biochar, the total nitrogen contents were $0.22 \%$ and $0.32 \%$, respectively. This showed that addition of biochar increased the total nitrogen of the experimental soil. In 
case of brinjal, total nitrogen content of the initial soil was $0.20 \%$ but after addition of biochar at the rate of $5 \mathrm{t} / \mathrm{ha}$, the total nitrogen increased to $0.41 \%$. The total nitrogen contents were $0.26 \%$ and $0.30 \%$ when biochar was applied at the rate of 1 and $3 \mathrm{t} / \mathrm{ha}$, respectively (Table 6). Similar results were reported by DeLuca et al. (2009) who stated that biochar added to soil with an organic $\mathrm{N}$ source. Biochar has the potential in holding ammonium nitrogen and thus reduce the loss of nitrogen from soils and therefore, increased nitrogen content in soils. Available phosphorous result reveals that application of biochar has significant effect among the treatments on the dynamics of phosphorous availability. Higher available phosphorus $(67.3 \mathrm{mg} / \mathrm{kg})$ was recorded from the soil treated with 3 t/ha biochar $+\mathrm{RF}$ of biochar in cauliflower field which is higher than the control plot and the lowest P $(44.11 \mathrm{mg} / \mathrm{kg})$ was observed in soil treated with $1 \mathrm{t} / \mathrm{ha}$ biochar RF of biochar (Table 6). In case of brinjal field, higher available phosphorus (68.05 $\mathrm{mg} / \mathrm{kg})$ was recorded from the soil treated with 5 t/ha biochar $+\mathrm{RF}$.

The effects of biochar application on available potassium contents in soil was highly significant $(p<0.05)$. The increased rates of biochar application increased the available potassium content in soil. The highest available potassium content $(0.34 \mathrm{meq} / 100 \mathrm{~g})$ in soil was found from $1 \mathrm{t} / \mathrm{ha}$ biochar $+\mathrm{RF}$ biochar application in cauliflower field. Similar result found in $3 \mathrm{t} / \mathrm{ha}$ biochar + RF and 5 t/ha biochar + RF which was $0.31 \mathrm{meq} / 100 \mathrm{~g}$ and $0.32 \mathrm{meq} / 100 \mathrm{~g}$ soil (Table $6)$. The lowest available potassium content $(0.27$ meq/100 $\mathrm{g}$ soil) was found from control plot and it was significantly $(\mathrm{p}<0.05)$ lower than other treatments. In case of brinjal, highest available potassium content $(0.47 \mathrm{meq} / 100 \mathrm{~g}$ soil $)$ in soil was found from $5 \mathrm{t} / \mathrm{ha}$ biochar $+\mathrm{RF}$ biochar application in cauliflower field. The lowest available potassium content $(0.32 \mathrm{meq} / 100 \mathrm{~g}$ soil) was found from control plot and it was significantly $(\mathrm{p}<0.05)$ lower than other treatments.
There was significant effect of the biochar rates on available sulfur in the experiment. The highest mean value of $S(7.38 \mathrm{mg} / \mathrm{kg})$ was recorded in case of $5 \mathrm{t} / \mathrm{ha}$ biochar $+\mathrm{RF}$ and significantly differ from other treatment in cauliflower field. But the effects of other treatments on soil sulfur were found statistically similar. In case of brinjal, the highest value of sulfur $(9.5 \mathrm{mg} / \mathrm{kg})$ was recorded in case of $5 \mathrm{t} / \mathrm{ha}$ biochar + RF and significantly differ from other treatment in cauliflower field. But $1 \mathrm{t} / \mathrm{ha}$ biochar $+\mathrm{RF}$ and 3 t/ha biochar $+\mathrm{RF}$ are statistically similar. The lowest available $\mathrm{S}$ content (3.8 $\mathrm{mg} / \mathrm{kg}$ ) was found in the control treatment which was significantly $(\mathrm{p}<0.05)$ lower than other treatments.

Because of larger surface area biochar facilitates the adherence of nutrient molecules to the many exchange sites on the biochar particles and its surrounding cloudy nutrient exchange environment. Thus biochar has the potential to reduce nutrient loss and increase their use efficiencies in crop production. It is reported that sole application of biochar to soil without added fertilizer also increased plant yield and nutrient availability (Ogawa and Okimori, 2010, Vaccari, Baronti, et al., 2011). Biochar itself generally contains high densities of nutrients, but also may improve the performance of added fertilizers due to its cation exchange capacity. Combined application of biochar with inorganic fertilizers has been shown to outperform compared to sole application of inorganic fertilizers and biochar (Schulz and Glaser, 2012).

\subsection{Effect of biochar on different nutrient use efficiency (NUE)}

Agronomic efficiencies of $\mathrm{N}, \mathrm{P}, \mathrm{K}$ and $\mathrm{S}$ of cauliflower and brinjal plot are presented in Table 7, where a significantly increased of agronomic efficiencies were noted in the plants grown in biochar treated plot. The highest agronomic efficiencies were observed in the treatment of $5 \mathrm{t} / \mathrm{ha}$ biochar $+\mathrm{RF}$ in brinjal and cauliflower plot. The lowest nutrient use efficiencies were observed in treatment of RF in both the cases. Higher efficiencies in nutrient use 
were attributed better running of crop and nutrient management practices (Rahman, 2013). The biochar at higher soil concentrations not only changed the nutrients available for plant growth but also changed the soil fertility (DeLuca et al. 2009).

Physiological efficiency of N, P, K and S were significantly increased with adding biochar. The highest nutrient use efficiencies were observed in the treatment of $5 \mathrm{t} / \mathrm{ha}$ biochar $+\mathrm{RF}$ in case of cauliflower plot and the lowest nutrient use efficiencies were observed in the treatment of RF. In case of brinjal, there is no significant results among the treatments in terms of physiological efficiency of $\mathrm{N}, \mathrm{P}, \mathrm{K}$ and $\mathrm{S}$. Rahman (2013) investigated the effects of different organic waste treatments on physiological efficiencies of $\mathrm{N}, \mathrm{P}$, and $\mathrm{K}$ under tomato experiment were found to be insignificant.

Recovery efficiencies of N, P, K and S of brinjal and cauliflower plot are summarized in Table 9 , where a significant statistical relationship was observed among the treatments and increased ratio of different recovery efficiencies were noted in the plants grown in soil treated with biochar. The recovery efficiencies were higher in the treatment of 5 t/ha biochar $+\mathrm{RF}$ and the lowest nutrient use efficiency was observed in the treatment of RF. Girma et al. (2017) have discussed that depending upon the nutrient absorption power of the crops and their utilization at the biochemical levels, crops may vary in the recovery of the applied nutrients.

Table 7. Effect of biochar on agronomic efficiency of N, P, K and S

\begin{tabular}{lcccccccc}
\hline Treatments & \multicolumn{3}{c}{ Agronomic efficiency (kg cauliflower or brinjal/kg nutrient uptake) } \\
\cline { 2 - 9 } & \multicolumn{3}{c}{ Cauliflower } & \multicolumn{5}{c}{ Brinjal } \\
\cline { 2 - 9 } & $\mathrm{N}$ & $\mathrm{P}$ & $\mathrm{K}$ & $\mathrm{S}$ & $\mathrm{N}$ & $\mathrm{P}$ & $\mathrm{K}$ & $\mathrm{S}$ \\
\hline Recommended & $7.31 \mathrm{~b}$ & $26.43 \mathrm{~b}$ & $8.22 \mathrm{~b}$ & $73.41 \mathrm{~b}$ & $4.98 \mathrm{~d}$ & $18 \mathrm{~d}$ & $5.60 \mathrm{~d}$ & $50.00 \mathrm{~d}$ \\
fertilizer (RF) & & & & & & & & \\
1 ton/ha Biochar + RF & $11.80 \mathrm{~b}$ & $42.64 \mathrm{~b}$ & $13.27 \mathrm{~b}$ & $118.45 \mathrm{~b}$ & $15.14 \mathrm{c}$ & $54.71 \mathrm{c}$ & $17.02 \mathrm{c}$ & $151.98 \mathrm{c}$ \\
3 ton/ha Biochar+ RF & $10 \mathrm{~b}$ & $36.14 \mathrm{~b}$ & $11.24 \mathrm{~b}$ & $100.40 \mathrm{~b}$ & $28.34 \mathrm{~b}$ & $102.43 \mathrm{~b}$ & $31.87 \mathrm{~b}$ & $284.52 \mathrm{~b}$ \\
5 ton/ha Biochar+ RF & $19.13 \mathrm{a}$ & $69.14 \mathrm{a}$ & $21.51 \mathrm{a}$ & $192.06 \mathrm{a}$ & $37.35 \mathrm{a}$ & $135 \mathrm{a}$ & $42 \mathrm{a}$ & $375.00 \mathrm{a}$ \\
\hline $\mathrm{CV}(\%)$ & 28.08 & 28.08 & 28.08 & 28.08 & 11.03 & 11.03 & 11.03 & 11.03 \\
$\mathrm{SE}( \pm)$ & 2.39 & 8.65 & 2.69 & 24.04 & 1.67 & 6.05 & 1.88 & 16.8 \\
\hline
\end{tabular}

Table 8. Effect of biochar on physiological efficiency of N, P, K and S

\begin{tabular}{|c|c|c|c|c|c|c|c|c|}
\hline \multirow[t]{3}{*}{ Treatments } & \multicolumn{8}{|c|}{ Physiological efficiency (kg cauliflower or brinjal/kg nutrient uptake) } \\
\hline & \multicolumn{4}{|c|}{ Cauliflower } & \multicolumn{4}{|c|}{ Brinjal } \\
\hline & $\mathrm{N}$ & $\mathrm{P}$ & $\mathrm{K}$ & $\mathrm{S}$ & $\mathrm{N}$ & $\mathrm{P}$ & $\mathrm{K}$ & $\mathrm{S}$ \\
\hline $\begin{array}{l}\text { Recommended } \\
\text { fertilizer (RF) }\end{array}$ & $74.97 b$ & $470.1 \mathrm{~b}$ & $125.62 b$ & $446.3 b$ & $68.76 \mathrm{a}$ & $251.13 \mathrm{a}$ & $223.24 \mathrm{a}$ & $261.56 \mathrm{ab}$ \\
\hline $\begin{array}{l}1 \text { ton } / \text { ha } \\
\text { Biochar + RF }\end{array}$ & $120.97 b$ & $758.6 b$ & $77.47 b$ & $720.1 b$ & $74.13 \mathrm{a}$ & $296.91 \mathrm{a}$ & $265.84 \mathrm{a}$ & $349.87 \mathrm{a}$ \\
\hline $\begin{array}{l}3 \text { ton/ha } \\
\text { Biochar+ RF }\end{array}$ & $102.53 b$ & $642.9 b$ & $65.66 \mathrm{~b}$ & $610.4 b$ & $63.64 \mathrm{a}$ & $232.62 \mathrm{a}$ & $190.38 \mathrm{ab}$ & $284.61 \mathrm{ab}$ \\
\hline $\begin{array}{l}5 \text { ton/ha } \\
\text { Biochar+ RF }\end{array}$ & $196.15 \mathrm{a}$ & $1230 \mathrm{a}$ & $125.62 \mathrm{a}$ & $1167.7 \mathrm{a}$ & $60.82 \mathrm{a}$ & $242.75 a$ & $137.31 b$ & $237.44 b$ \\
\hline $\mathrm{CV}(\%)$ & 28.08 & 28.08 & 28.08 & 28.08 & 25.89 & 20.79 & 25.64 & 20.16 \\
\hline $\mathrm{SE}( \pm)$ & 24.55 & 153.96 & 15.72 & 146.16 & 12.23 & 37.62 & 37.01 & 40.39 \\
\hline
\end{tabular}


Table 9. Effect of biochar on recovery efficiency of N, P, K and S

\begin{tabular}{lcccccccc}
\hline Treatments & \multicolumn{7}{c}{ Recovery efficiency (\%) } \\
\cline { 2 - 9 } & \multicolumn{7}{c}{ Cauliflower } & \multicolumn{5}{c}{ Brinjal } \\
\cline { 2 - 9 } & $\mathrm{N}$ & $\mathrm{P}$ & $\mathrm{K}$ & $\mathrm{S}$ & $\mathrm{N}$ & $\mathrm{P}$ & $\mathrm{K}$ & $\mathrm{S}$ \\
\hline Recommended fertilizer & $11.21 \mathrm{c}$ & $7.06 \mathrm{c}$ & $15.01 \mathrm{~b}$ & $21.67 \mathrm{c}$ & $7.42 \mathrm{~d}$ & $7.597 \mathrm{~d}$ & $2.51 \mathrm{~d}$ & $14.78 \mathrm{~d}$ \\
(RF) & & & & & & & & \\
1 ton/ha Biochar + RF & $30.13 \mathrm{~b}$ & $9.14 \mathrm{bc}$ & $26.24 \mathrm{~b}$ & $44.31 \mathrm{~b}$ & $20.83 \mathrm{c}$ & $18.61 \mathrm{c}$ & $6.63 \mathrm{c}$ & $39.98 \mathrm{c}$ \\
3 ton/ha Biochar+ RF & $26.45 \mathrm{~b}$ & $13.61 \mathrm{~b}$ & $23.60 \mathrm{~b}$ & $45.24 \mathrm{~b}$ & $44.45 \mathrm{~b}$ & $44.24 \mathrm{~b}$ & $16.95 \mathrm{~b}$ & $96.25 \mathrm{~b}$ \\
5 ton/ha Biochar+ RF & $46.47 \mathrm{a}$ & $26.71 \mathrm{a}$ & $44.96 \mathrm{a}$ & $74.86 \mathrm{a}$ & $61.89 \mathrm{a}$ & $57.28 \mathrm{a}$ & $30.67 \mathrm{a}$ & $153.89 \mathrm{a}$ \\
\hline $\mathrm{CV}(\%)$ & 23.02 & 25.30 & 26.44 & 22.34 & 16.05 & 20.21 & 14.25 & 12.69 \\
SE $( \pm)$ & 4.65 & 2.53 & 5.13 & 7.35 & 3.82 & 4.56 & 1.43 & 6.84 \\
\hline
\end{tabular}

\section{Conclusions}

Biochar improves nutrients availability in soils through improving soil chemical, physical and biological properties. Studies have proved that biochar has a great potential to enhance soil fertility and crop productivity by reducing soil acidity, increasing CEC, increasing soil organic matter and nutrient retention and plant nutrient availability. The yields of cauliflower and brinjal were also increased with the application of biochar compared to the recommended sole inorganic fertilizers. The maximum yields of cauliflower and brinjal were found 42 and 67 $\mathrm{t} / \mathrm{ha}$ when biochar was applied at the rate of 5 t/ha. Carbon stocks in soil were increased with application of biochar where organic carbon increased by 25 to $41 \%$ from the initial levels.

\section{Acknowledgements}

The research was supported by the Biochar and Organic Farming Program of Christian Commission for Development in Bangladesh (CCDB).

\section{References}

An S., Mentler A., Mayer H., Blum WE. 2010. Soil aggregation, aggregate stability, organic carbon and nitrogen in different soil aggregate fractions under forest and shrub vegetation on the Loess Plateau, China. Catena, 81(3): 226-233.
Beesley L., Moreno-Jimenez E., Gomez-Eyles JL., Harris E., Robinson B., Sizmur T. 2011. A review of biochars' potential role in the remediation, revegetation and restoration of contaminated soils. Environmental Pollution, 159(12) : 3269-3282.

Biederman LA., Harpole WS. 2013. Biochar and its effects on plant productivity and nutrient cycling: a meta-analysis. $G C B$ Bioenergy, 5(2) : 202-214.

Chan KY., Van Zwieten L., Meszaros I., Downie A., Joseph S. 2008. Agronomic values of greenwaste biochar as a soil amendment. Soil Research,45(8) : 629634.

DeLuca TH., Gundale MJ., MacKenzie MD., Jones DL. 2015. Biochar effects on soil nutrient transformations. Biochar for Environmental Management: Science, Technology and Implementation, 2: 421454.

FRG. 2012. Fertilizer Recommendation Guide, 2012.BARC (Bangladesh Agricultural Research Council), Farmgate, Dhaka.

Girma T., Beyene S., Biazin B. 2017. Effect of organic and inorganic fertilizer application on soil phosphorous balance and phosphorous uptake and use efficiency of potato in Arbegona District, 
Southern Ethiopia. Journal of Fertilizers \& Pesticides, 8: 1-6.

Kimetu JM., Lehmann J., Ngoze SO., Mugendi DN., Kinyangi JM., Riha S., Pell AN. 2008. Reversibility of soil productivity decline with organic matter of differing quality along a degradation gradient. Ecosystems, 11(5): 726.

Laird DA., Fleming P., Davis DD., Horton R., Wang B., Karlen DL. 2010. Impact of biochar amendments on the quality of a typical Midwestern agricultural soil. Geoderma, 158(3-4): 443-449.

Lal R. 2004. Soil carbon sequestration impacts on global climate change and food security. Science, 304(5677): 1623-1627.

Lehmann J. 2007. A handful of carbon. Nature, 447(7141): 143-144.

Lehmann J., da Silva JP., Steiner C., Nehls T., Zech W., Glaser B. 2003. Nutrient availability and leaching in an archaeological Anthrosol and a Ferralsol of the Central Amazon basin: fertilizer, manure and charcoal amendments. Plant and Soil, 249(2): 343-357.

Lehmann J., Rillig MC., Thies J., Masiello CA., Hockaday WC., Crowley D. 2011. Biochar effects on soil biota-a review. Soil biology and Biochemistry, 43(9): 1812-1836.

Lim TJ., Spokas KA., Feyereisen G., Novak JM. 2016. Predicting the impact of biochar additions on soil hydraulic properties. Chemosphere, 142: 136-144.

Major J., Lehmann J., Rondon M., Goodale C. 2010. Fate of soil-applied black carbon: downward migration, leaching and soil respiration. Global

Change Biology, 16(4): 1366-1379.

Ogawa M., Okimori Y. 2010. Pioneering works in biochar research, Japan. Soil Research, 48(7): 489-500.
Rahman F., Rahman MM., Rahman GKMM., Saleque MA., Hossain AS., Miah MG. 2016. Effect of organic and inorganic fertilizers and rice straw on carbon sequestration and soil fertility under a rice-rice cropping pattern. Carbon Management, 7(1-2): 41-53.

Rahman MM. 2013. Nutrient-use and carbonsequestration efficiencies in soils from different organic wastes in rice and tomato cultivation. Communications in Soil Science and Plant Analysis, 44(9): 1457-1471.

Rahman MM., Azam GM. 2005. Fertility evaluation of Old Meghna River Floodplain soils in Bangladesh for sustainable agriculture. Chiang Mai Journal of Science, 32(2): 127-137.

Schulz H., Glaser B. 2012. Effects of biochar compared to organic and inorganic fertilizers on soil quality and plant growth in a greenhouse experiment. Journal of Plant Nutrition and Soil Science, 175(3): 410-422.

Sohi S., Lopez-Capel E., Krull E., Bol R. 2009. Biochar, climate change and soil: A review to guide future research. CSIRO Land and Water Science Report, 5(09): 17-31.

Steiner C., Glaser B., Geraldes TW., Lehmann J., Blum WE., Zech W. 2008. Nitrogen retention and plant uptake on a highly weathered central Amazonian Ferralsol amended with compost and charcoal. Journal of Plant Nutrition and Soil Science, 171(6): 893-899.

Steiner C., Teixeira WG., Lehmann J., Nehls T., de Macedo JLV., Blum WE., Zech W. 2007. Long term effects of manure, charcoal and mineral fertilization on crop production and fertility on a highly weathered Central Amazonian upland soil. Plant and Soil, 291(1-2): 275-290. 
Suzuki K., Matsunaga R., Hayashi K., Matsumoto N., Tabo R., Tobita S., Okada K. 2014. Effects of traditional soil management practices on the nutrient status in Sahelian sandy soils of Niger, West Africa. Geoderma, 223: 1-8.

Uzoma KC., Inoue M., Andry H., Fujimaki H., Zahoor A., Nishihara E. 2011. Effect of cow manure biochar on maize productivity under sandy soil condition. Soil Use and Management, 27(2): 205-212.

Vaccari FP., Baronti S., Lugato E., Genesio L., Castaldi S., Fornasier F., Miglietta, F. 2011. Biochar as a strategy to sequester carbon and increase yield in durum wheat. European Journal of Agronomy, 34(4): 231-238.

Warnock DD., Lehmann J., Kuyper TW., Rillig MC. 2007. Mycorrhizal responses to biochar in soil-concepts and mechanisms. Plant and Soil, 300(1-2): 920.
Woolf D., Amonette JE., Street-Perrott FA., Lehmann J., Joseph S. 2010. Sustainable biochar to mitigate global climate change. Nature Communications, 1: 56.

Yamato M., Okimori Y., Wibowo IF., Anshori S., Ogawa M. 2006. Effects of the application of charred bark of Acacia mangium on the yield of maize, cowpea and peanut, and soil chemical properties in South Sumatra, Indonesia. Soil Science and Plant Nutrition, 52(4): 489-495.

Yao Y., Gao B., Chen J., Yang L. 2013. Engineered biochar reclaiming phosphate from aqueous solutions: mechanisms and potential application as a slow-release fertilizer. Environmental Science \& Technology, 47(15): 8700-8708.

Yuan JH., Xu RK., Zhang H. 2011. The forms of alkalis in the biochar produced from crop residues at different temperatures. Bioresource Technology, 102(3): 3488-3497. 